\title{
Retesting the Monetary Approach to Foreign Exchange Rates: The Case of the US Dollar
}

\author{
Samih Antoine Azar \\ Correspondence: Samih Antoine Azar, Associate Professor, Faculty of Business Administration \& Economics, \\ Haigazian University, Mexique Street, Kantari, Beirut, Lebanon. Tel: 96-11-349-230. E-mail: \\ samih.azar@haigazian.edu.lb
}

Received: December 3, 2012

Accepted: December 27, 2012

Online Published January 10, 2013

doi:10.5539/ijef.v5n2p56

URL: http://dx.doi.org/10.5539/ijef.v5n2p56

\begin{abstract}
This paper estimates successfully a version of the monetary approach to foreign exchange rates applied to the US dollar for the post-1973 floating exchange rate period. Although this approach has lately fallen in disrepute, the statistical evidence is strongly in support of the model. The results conform to expectations. All coefficients have the correct sign and are highly significant statistically. The null hypothesis that the coefficient on the money stock variable is equal to +1 fails to be rejected in all four estimated regressions. This reflects money neutrality. The null hypothesis that the coefficient on the scale variable is equal to -1 fails to be rejected in all these four regressions. This means that there are neither economies nor diseconomies of scale for aggregate income. The joint null hypothesis that both of the above two constraints hold fails to be rejected at marginal significance levels much higher than $10 \%$ for the first two regressions and fails to be rejected at a marginal significance level higher than $2 \%$ for the last two regressions. Finally, the adjustment to the long run falls upon the real interest rate and probably upon the scale variable. There is evidence that the foreign exchange rate, the money supply, and the nominal interest rate are all weakly exogenous. One implication of this study is that businesses, economists, individual investors, central bankers and policy-makers should have a more benign look upon fluctuations in foreign exchange rates, and should become convinced that these fluctuations are determined by fundamental forces.
\end{abstract}

Keywords: US dollar foreign exchange rate, money demand, cointegration, likelihood ratio tests, money neutrality, economies of scale, vector error-correction model

JEL codes: F31, E41, F41, C58, C32.

\section{Introduction}

There is no doubt that floating foreign exchange rates are volatile. Since 1973 the mean of the log returns, i.e. the mean of the first-difference of the natural logarithms, of the trade-weighted foreign exchange rate of the US dollar recorded an annualized standard deviation of 5.99\%. Log returns are approximately equal to percentage changes particularly when the frequency of the data is high. Obviously, bilateral foreign exchange rates of the US dollar have a higher volatility than the trade-weighted one because there is no averaging. In Azar (2012a) bilateral annualized volatilities of the US dollar are estimated to be $7.13 \%$ for the Canadian dollar, $10.12 \%$ for the sterling pound, and $11.49 \%$ for the Japanese yen.

An annualized volatility of $5.99 \%$ is higher than the annual inflation rate volatility which is $4.2 \%$ (Ross et al., 2010), but compares well with interest rate volatilities. For example, Ross et al. (2010) document an annual volatility of $5.7 \%$ for intermediate-term government bonds. However, foreign exchange rates are relative asset prices and their volatility should be compared to other asset price volatilities. A commodity like oil has an annualized volatility of $33.08 \%$ (Azar, 2012a). A portfolio of large-company stocks has an annual volatility of $20.6 \%$, while the annual stock volatility of some individual firms, like that of Amazon, can reach up to $78.05 \%$ (Ross et al., 2010). Therefore, the volatility of foreign exchange rates is significantly less than that of asset prices. This does not preclude the fact that foreign exchange rates are highly variable in an absolute sense.

Since the volatility of foreign exchange rates is well established, the question that arises is whether this volatility can be explained, macro-economically, by fundamentals. In this regard short run volatility is likely to be too noisy, but long run volatility may be more amenable to modeling. This is the purpose of this paper: to test whether the US dollar is anchored in the long run to fundamentals. If a proper model exists then the appropriate 
long run relation can be found by applying cointegration techniques (Engle and Granger, 1987; Johansen, 1991, 1995). Cointegration, if it fails to be rejected, implies that the variables in the multiple regression equation move together in the long run, or, in other terms, they are anchored to each other. Of course, as will become evident below, some special data characteristics need to obtain and certain sign and coefficient restrictions need to be imposed and tested. Otherwise the model will not conform to theory.

The theoretical model adopted in this paper is what is known as the monetary approach to foreign exchange rates. This model was popular in the late seventies (Bilson, 1978; Dornbusch, 1980; Hodrick, 1978) but went into disrepute later. The turning point was Meese and Rogoff (1983), who found that a random walk model of the foreign exchange rate outperforms in forecasting ability the predictions of all other theoretical and macroeconomic models. Nonetheless, some more recent and supportive empirical analyses of the monetary model showed up in the 2000s (Groen, 2000; Rapach and Wohar, 2002). Lizardo and Mollick (2010) use the same monetary model to test for the effect of real oil prices and their evidence on the model is mixed. Some coefficients, that turn out to be statistically significant, have the wrong signs. In addition, many coefficients are not statistically significant.

If the monetary model is validated by statistical analysis this is an important step in the direction of explaining the determinants of foreign exchange rates. In such a case the implications are substantial. First, economists should regain confidence in the model, and should be assured that foreign exchange rate fluctuations are justified by the fundamentals included in the model. At the very least, volatility of foreign exchange rates may fail to be regarded as excessive, especially in the long run. There are also policy implications. Policy makers and central bankers should have another and more benign look upon foreign exchange rate changes and should come to believe that the latter do not move "out of hand." Firms and businesses should become persuaded that in the long run they can forecast the level and volatility of foreign exchange rates, and that they need not put too much attention on short run unpredictability. Individual investors should be more tranquil about the returns on their foreign investments and these returns should turn out to be better in line with their expectations.

The monetary approach to foreign exchange rates, as the name indicates, relies on a stable money demand relation. If $m$ is the natural log of the money stock, $y$ is the log of aggregate output, $p$ is the log of the price level, $i$ is the nominal interest rate, and $\alpha, \beta$, and $\gamma$ are regression coefficients then the money demand relation can be stated as follows, with $\varepsilon$ as a regression residual:

$$
m-p=\alpha+\beta y+\gamma i+\varepsilon \quad \text { with } \beta>0 \quad \text { and } \gamma<0
$$

In equation (1) $\beta$ should be close to +1 . However, this depends on the proxy utilized for the variable $y$. Rearranging equation (1) and ignoring the interest rate effect then one has:

$$
p=-\alpha+\lambda m-\beta y+\varepsilon \quad \text { with } \lambda=1
$$

Equation (2) has been estimated by cointegration methods for commodity indexes as the price variable using monthly data (Azar, 2012b) or quarterly data (Browne and Cronin, 2007, 2010), for individual monthly commodity prices as the price level (Azar, 2012a, 2012c), and for individual monthly commodity futures as the price level (Azar, 2012d). The relevance of this literature to this paper is threefold. One, the existence of a long run relation is supported. Two, the price level is replaced by prices set in auction markets that are characterized by high flexibility and high volatility that come close to the flexibility and volatility of foreign exchange rates. Three, the coefficient on the money supply $(\lambda)$ turns out to be invariably statistically insignificantly different from +1 whatever the way the price level is defined.

The rest of the paper is organized as follows. The theoretical model is presented in section 2. The data source, the empirical results and their interpretation form the major part of section 3. The last section summarizes and concludes.

\section{The Theory}

The first theoretical construct is the Fisher equation (Fisher, 1930). The nominal rate of return has two components: the real rate of return and expected inflation. If $r_{t}$ is the real rate at time $t$, sometimes called the ex ante real rate, if $i_{t}$ is the nominal rate, and if $E_{t}\left(\pi_{t+1}\right)$ is expected inflation, with $E_{t}$ being the expectation operator, then the following relation is true:

$$
r_{t}=\frac{\left(1+i_{t}\right)}{\left(1+E_{t}\left(\pi_{t+1}\right)\right)}-1=\frac{i_{t}-E_{t}\left(\pi_{t+1}\right)}{\left(1+E_{t}\left(\pi_{t+1}\right)\right)} \approx i_{t}-E_{t}\left(\pi_{t+1}\right)
$$


In equation (3) the reason why the nominal and real rates are indexed with $t$ and the inflation rate is indexed with $t+1$ is due to the fact that rates of returns are usually known in advance, especially if they are rates of interest. The approximation in equation (3) holds well since the data in this paper is monthly. In such a case:

$$
1+E_{t}\left(\pi_{t+1}\right) \approx 1
$$

The second construct is the definition of the real foreign exchange rate. If $S_{t}$ is the nominal foreign exchange rate at time $t$, measured as the number of units of the domestic currency per one unit of the foreign currency, if $P_{t}$ is the domestic price level, and if $P_{t}^{*}$ is the foreign price level, then the following is true:

$$
\text { Real exchange rate }=X_{t}=\frac{S_{t} P_{t}^{*}}{P_{t}}
$$

In equation (5) a depreciation of the nominal or of the real foreign exchange rate is an increase in value. Taking natural $\operatorname{logs}(m)$ in equation (5) then:

$$
\ln \left(X_{t}\right)=\ln \left(\frac{S_{t} P_{t}^{*}}{P_{t}}\right)=\ln \left(S_{t} P_{t}^{*}\right)-\ln \left(P_{t}\right)
$$

Equation (6) states that the log of the real foreign exchange rate is composed of two elements: the domestic loss in purchasing power of the US dollar $\left(\ln \left(P_{t}\right)\right)$, and the foreign loss in purchasing power of the US dollar $\left(\ln \left(S_{t} P_{t}^{*}\right)\right)$. Since in this paper the trade-weighted exchange rate of the US dollar is used, this corresponds to the average foreign purchasing power of the US dollar, i.e. it stands for $\left(\ln \left(S_{t} P_{t}^{*}\right)\right)$ and not for $\left(\ln \left(S_{t}\right)\right)$. Define, for simplicity, the log of the trade-weighted exchange rate of the US dollar $\left(\ln \left(S_{t} P_{t}^{*}\right)\right)$ as $\left(\ln \left(Z_{t}\right)\right)$. The actual data on this trade-weighted rate is provided as the number of units of foreign currency per one unit of the US dollar. In order to be consistent with the definition of $\left(Z_{t}\right)$ in this paper the inverse of the published series must be taken, or, in the log formulation, the log of the inverse of the published series, which equals minus the log of the published series, is to be computed.

The third construct is that the log of the real exchange rate is explained by the difference in real interest rates, i.e. the difference between the domestic real interest rate $(r)$ and the foreign real interest rate $\left(r^{*}\right)$. If the relation is linear then:

$$
\ln \left(X_{t}\right)=\ln \left(\frac{S_{t} P_{t}^{*}}{P_{t}}\right)=\ln \left(Z_{t}\right)-\ln \left(P_{t}\right)=\delta+\phi\left(r_{t}-r_{t}^{*}\right)+\varepsilon_{t} \quad \text { with } \phi<0
$$

Equation (7) is consistent with the Mundell-Fleming IS/LM open macroeconomic model with capital mobility (Fleming, 1962; Mundell, 1968) whereby a higher differential in real interest rates, between the domestic and foreign country, appreciates the real exchange rate. It is also partly consistent with the NATREX (Natural Real Exchange Rate) approach to real exchange rates (Rey, 2009; Stein et al., 1997). Below another specification of the model will be derived that is more compatible with Stein et al. (1997) and Rey (2009).

Two problems surface with equation (7). One, the real interest rates require knowledge about expected differential inflation rates. An approximation is used by taking the ex post real interest rate, instead of the ex ante interest rate in equation (3). The ex post real interest rate is defined as:

$$
i_{t}-\pi_{t+1}
$$

There is no doubt that the approximation in equation (8) creates a problem of measurement error in the real interest rate variable. However, as long as the measurement error is stationary then the problem is relatively minor.

The second problem is in trying to measure or in defining a proxy for the real foreign interest rate. Since this real foreign rate must include real rates of all countries with which the US trades, and since some of these countries have higher real rates while others have lower real rates, it is expected that, on average, the weighted real foreign rate of interest is little variable, if at all, and can be ignored. One should recall that, in regression analysis, a fundamental requirement for statistical precision is that each regressor be variable enough.

The fourth construct is the money demand relation that includes the nominal interest rate. If this money demand is solved for the log of the price level $\ln \left(P_{t}\right)$, that was defined as $p$ in equations (1) and (2), then one has:

$$
\ln \left(Z_{t}\right)-\ln \left(P_{t}\right)=\delta+\phi\left(r_{t}-r_{t}^{*}\right) \Rightarrow \ln \left(Z_{t}\right) \approx \delta+\phi r_{t}+\lambda m_{t}+\beta y_{t}+\gamma_{t}+\varepsilon_{t}
$$

In equation (9) $\gamma$ is the semi-elasticity of money demand of the nominal interest rate. The following sign restrictions must hold: 


$$
\phi<0, \lambda>0, \quad \beta<0, \quad \gamma>0
$$

In addition, the following size restrictions should bind:

$$
\lambda=1, \quad \beta=-1
$$

The second size restriction in (11), i.e. $\beta=-1$, depends on the proxy selected for the scale variable $y$. Another specification of the same model is a log-log relation with the nominal interest rate:

$$
\ln \left(Z_{t}\right) \approx \delta+\phi r_{t}+\lambda m_{t}+\beta y_{t}+\theta\left(\ln \left(i_{t}\right)\right)+\varepsilon_{t}
$$

In this case $\theta$ is the elasticity of money demand of the nominal interest rate, and should also be positive in sign. The same sign restrictions (equations (10)) and size restrictions (equations (11)) apply for equation (12) as they do for equation (9). Equations (9) and (12) compare better with the NATREX model that includes a domestic productivity variable that Stein et al. (1997) and Rey (2009) proxy by the domestic growth in income. The variables $m$ and $i$ are not present in the NATREX model which includes however foreign growth and domestic government expenditures, both of which are not directly part of equations (9) and (12). If government expenditures are related to aggregate output then these expenditures appear indirectly in these equations through the output variable. However, there is a complication: are these expenditures positively or negatively related to output? In Stein et al. (1997) and Rey (2009) the effect of government expenditures on the NATREX, the natural real exchange rate, is opposite to that of domestic growth. Higher government spending reduces saving, while domestic growth increases saving. The Keynesian IS/LM analysis would predict that the two variables should have the same effect because higher government expenditures generate a higher output, at least in the short run. In the long run however, if there is enough capital mobility, fiscal policy is ineffective and neutral when foreign exchange rates are flexible and floating.

A salient feature of the NATREX model and of the monetary model, as exemplified by equations (9) and (12), is that an increase in domestic aggregate output appreciates the foreign exchange rate. The traditional balance of payments view of the foreign exchange rate predicts the opposite effect (MacDonald, 1988): higher domestic output is reflected by higher imports, a deterioration of the trade balance, and a depreciation of the foreign exchange rate.

\section{The Empirical Results}

The source of all data is from the website of the Federal Reserve Bank of Saint Louis. The data consists of the trade-weighted foreign exchange rate of the US dollar, the seasonally adjusted MZM money stock, the MZM money stock that is not seasonally adjusted, the industrial production index, the 10-year Treasury rate, the Moody's aaa corporate bond yield, and the Consumer Price Index (all items). The choice of the MZM money stock, instead of M2, derives from the fact that the former is more popular according to the same web site. The use of the industrial production index as a scale variable, or as a proxy for aggregate output, follows the tradition initiated by Fama (1981). All the data is monthly and span the period from January 1973 to July 2012. This corresponds to the floating period of the foreign exchange rate of the US dollar. The total number of observations per variable is 475 , except for the real rate which has 474 observations.

In order to undertake cointegration analysis, the variables must be tested for stationarity. The condition is that all variables need to be non-stationary with the same degree of integration. The first step is to specify the maximum lag length of the unit root test because the latter is sensitive to this lag length. If $N$ is the sample size, then the maximum number of lags is equal to the integer number of the factor $N^{0.25}$ (Diebold and Nerlove, 1990; Mills, 1999; Mills and Markellos, 2008; Schwert, 1987). Since the sample size is composed of 475 observations this rule provides a result of $475^{0.25}=4.67$, which is rounded to 5 . The results of the Elliott-Rothenberg-Stock point optimal unit root test (Elliott et al., 1996), with the presence of a trend, are presented in Table 1.

The log of the trade-weighted foreign exchange rate of the US dollar, the logs of the two US money supply series, the log of the US industrial production index, and the log of the 10-year Treasury rate are all non-stationary in levels but stationary in first-differences. Therefore all are integrated of order one. The 10-year Treasury rate is also integrated of the same order. However the ex post real US rate is stationary in levels and in first-differences. However, if the KPSS test (Kwiatkowski et al., 1992), with a constant but without a trend, is applied on the ex post real US rate, this variable turns out to be integrated of order one. Hence in what follows all variables are considered integrated of order one and cointegration tests can proceed without any problem. 
Table 1. Elliott-Rothenberg-Stock point-optimal unit root tests with a constant and a linear trend. The maximum lag is set to 5 . The null hypothesis is a unit root

\begin{tabular}{lcc}
\hline \multicolumn{1}{c}{ Variable } & $\begin{array}{c}\text { Test statistic } \\
\text { on the level }\end{array}$ & $\begin{array}{c}\text { Test statistic on the } \\
\text { first-difference }\end{array}$ \\
\hline Log of US the trade-weighted foreign exchange rate & 8.454339 & 1.036214 \\
Log of the US MZM money stock (seasonally adjusted) & 8.979281 & 0.554572 \\
Log of the US MZM money stock (not seasonally adjusted) & 5.988808 & 1.817775 \\
Log of the US industrial production index & 7.377106 & 1.946514 \\
The US 10-year Treasury rate & 26.41814 & 0.283635 \\
Log of the US 10-year Treasury rate & 22.43756 & 0.306432 \\
Ex post US real interest rate & 2.195923 & 3.505309 \\
\hline
\end{tabular}

Notes: the critical values for the test are $3.96(1 \%), 5.62(5 \%)$, and $6.89(10 \%)$. The ex post US real interest rate is the Moody's aaa corporate bond yield minus actual inflation. US inflation is measured by the log change of the US Consumer Price Index (all items).

Testing for cointegration is to be preceded by determining the specification and the optimal number of lags. The default specification is adopted, meaning that a constant, but no trend, is included. The optimal lag length is selected by minimizing the Akaike Information Criterion (Akaike, 1974). This criterion opts for three lags in all four cointegration regressions. These four regressions consist of equations (9) and (12) with either the seasonally adjusted money stock or the money stock that is not seasonally adjusted.

Table 2. Johansen cointegration tests. The lag length is 3 for all regressions and these include a constant but not a trend

Equation (9) in the text using the seasonally adjusted money stock

\begin{tabular}{|c|c|c|c|c|c|c|c|}
\hline $\begin{array}{l}\text { Hypothesized number of } \\
\text { cointegration equations }\end{array}$ & Eigen value & Trace statistic & $\begin{array}{c}5 \% \text { critical } \\
\text { value }\end{array}$ & Probability & $\begin{array}{c}\text { Maximum } \\
\text { Eigen value }\end{array}$ & $\begin{array}{c}5 \% \text { critical } \\
\text { value }\end{array}$ & Probability \\
\hline None & 0.165698 & 133.6561 & 69.81889 & 0.0000 & 85.14506 & 33.87687 & 0.0000 \\
\hline At most 1 & 0.052083 & 48.51101 & 47.85613 & 0.0433 & 25.13959 & 27.58434 & 0.0996 \\
\hline At most 2 & 0.025601 & 23.37142 & 29.79707 & 0.2283 & 12.18900 & 21.13162 & 0.5291 \\
\hline At most 3 & 0.019554 & 11.18242 & 15.49471 & 0.2005 & 9.281615 & 14.26460 & 0.2635 \\
\hline At most 4 & 0.004036 & 1.900809 & 3.841466 & 0.1680 & 1.900809 & 3.841466 & 0.1680 \\
\hline \multicolumn{8}{|c|}{ Equation (9) in the text using the not seasonally adjusted money stock } \\
\hline $\begin{array}{l}\text { Hypothesized number of } \\
\text { cointegration equations }\end{array}$ & Eigen value & Trace statistic & $\begin{array}{c}5 \% \text { critical } \\
\text { value }\end{array}$ & Probability & $\begin{array}{l}\text { Maximum } \\
\text { Eigen value }\end{array}$ & $\begin{array}{c}5 \% \text { critical } \\
\text { value }\end{array}$ & Probability \\
\hline None & 0.167781 & 136.3031 & 69.81889 & 0.0000 & 86.32012 & 33.87687 & 0.0000 \\
\hline At most 1 & 0.055126 & 49.98297 & 47.85613 & 0.0311 & 26.65081 & 27.58434 & 0.0655 \\
\hline At most 2 & 0.025922 & 23.33217 & 29.79707 & 0.2301 & 12.34395 & 21.13162 & 0.5141 \\
\hline At most 3 & 0.019032 & 10.98822 & 15.49471 & 0.2122 & 9.031291 & 14.26460 & 0.2836 \\
\hline At most 4 & 0.004155 & 1.956926 & 3.841466 & 0.1618 & 1.956926 & 3.841466 & 0.1618 \\
\hline \multicolumn{8}{|c|}{ Equation (12) in the text using the seasonally adjusted money stock } \\
\hline $\begin{array}{l}\text { Hypothesized number of } \\
\text { cointegration equations }\end{array}$ & Eigen value & Trace statistic & $\begin{array}{c}5 \% \text { critical } \\
\text { value }\end{array}$ & Probability & $\begin{array}{c}\text { Maximum } \\
\text { Eigen value } \\
\end{array}$ & $\begin{array}{c}5 \% \text { critical } \\
\text { value }\end{array}$ & Probability \\
\hline None & 0.166402 & 130.7068 & 69.81889 & 0.0000 & 85.54182 & 33.87687 & 0.0000 \\
\hline At most 1 & 0.042224 & 45.16493 & 47.85613 & 0.0876 & 20.27648 & 27.58434 & 0.3223 \\
\hline At most 2 & 0.030657 & 24.88844 & 29.79707 & 0.1655 & 14.63405 & 21.13162 & 0.3154 \\
\hline At most 3 & 0.017093 & 10.25439 & 15.49471 & 0.2617 & 8.102952 & 14.26460 & 0.3683 \\
\hline At most 4 & 0.004567 & 2.151440 & 3.841466 & 0.1424 & 2.151440 & 3.841466 & 0.1424 \\
\hline \multicolumn{8}{|c|}{ Equation (12) in the text using the not seasonally adjusted money stock } \\
\hline $\begin{array}{l}\text { Hypothesized number of } \\
\text { cointegration equations }\end{array}$ & Eigen value & Trace statistic & $\begin{array}{l}5 \% \text { critical } \\
\text { value }\end{array}$ & Probability & $\begin{array}{l}\text { Maximum } \\
\text { Eigen value }\end{array}$ & $\begin{array}{l}5 \% \text { critical } \\
\text { value }\end{array}$ & Probability \\
\hline None & 0.167711 & 132.2578 & 69.81889 & 0.0000 & 86.28075 & 33.87687 & 0.0000 \\
\hline At most 1 & 0.042766 & 45.97707 & 47.85613 & 0.0743 & 20.54270 & 27.58434 & 0.3048 \\
\hline At most 2 & 0.031730 & 25.43437 & 29.79707 & 0.1465 & 15.15497 & 21.13162 & 0.2782 \\
\hline At most 3 & 0.016859 & 10.27940 & 15.49471 & 0.2598 & 7.991191 & 14.26460 & 0.3796 \\
\hline At most 4 & 0.004857 & 2.288210 & 3.841466 & 0.1304 & 2.288210 & 3.841466 & 0.1304 \\
\hline
\end{tabular}


Table 2 presents the Johansen cointegration tests (Johansen, 1991, 1995). Since there are five variables then four cointegration equations at most can exist for each regression. In all four regressions the hypothesis that there is one cointegration equation is strongly supported. The Johansen maximum Eigen value test statistic always rejects the presence of two or more cointegration equations per regression at conventional marginal significance levels. However, the trace test statistic finds some evidence for two cointegration equations in the two estimations of equation (9), with the two definitions of the money stock. In this case, although the two marginal significance levels are lower than $5 \%$ they are still higher than 3\%. As for the estimation of equation (12), and for the two definitions of the money stock, one cointegration equation is supported by both the trace test statistic and the maximum Eigen value test statistic. Decision is taken to conclude that there is only one cointegration equation in all four regressions.

Table 3 reports the estimated coefficient slopes for all variables in all four cointegration regressions. All sign restrictions are met and are according to expectations. A higher money stock depreciates the US dollar. A higher scale variable appreciates the US dollar. The effect of the nominal interest rate is positive, i.e. a higher nominal rate depreciates the US dollar, while the effect of the real interest rate is negative, i.e. a higher real rate appreciates the US dollar.

Table 3. Long run coefficients and likelihood ratio (LR) hypothesis tests

\begin{tabular}{|c|c|c|c|c|}
\hline & $\begin{array}{c}\text { Equation (9) } \\
\text { with the seasonally } \\
\text { adjusted money stock }\end{array}$ & $\begin{array}{c}\text { Equation (9) } \\
\text { with the not seasonally } \\
\text { adjusted money stock } \\
\end{array}$ & $\begin{array}{c}\text { Equation (12) } \\
\text { with the seasonally } \\
\text { adjusted money stock }\end{array}$ & $\begin{array}{c}\text { Equation (12) } \\
\text { with the not seasonally } \\
\text { adjusted money stock }\end{array}$ \\
\hline constant & -5.837647 & -5.791516 & -6.109887 & -6.098457 \\
\hline $\begin{array}{l}\text { Coefficient on the money } \\
\text { supply } \\
\text { (t-statistic) } \\
\text { [standard error] }\end{array}$ & $\begin{array}{l}0.681901 \\
(5.46958) \\
{[0.12467]} \\
\end{array}$ & $\begin{array}{l}0.702784 \\
(5.56423) \\
{[0.12630]} \\
\end{array}$ & $\begin{array}{l}0.849848 \\
(6.87041) \\
{[0.12370]} \\
\end{array}$ & $\begin{array}{l}0.866911 \\
(6.90178) \\
{[0.12561]} \\
\end{array}$ \\
\hline $\begin{array}{ll}\text { Coefficient } & \text { on the } \\
\text { industrial production } \\
\text { index } \\
\text { (t-statistic) } \\
\text { [standard error] }\end{array}$ & $\begin{array}{l}-1.015794 \\
(-2.90644) \\
{[0.34950]} \\
\end{array}$ & $\begin{array}{r}-1.065342 \\
(-3.00868) \\
{[0.35409]} \\
\end{array}$ & $\begin{array}{l}-1.421345 \\
(-4.52181) \\
{[0.31433]} \\
\end{array}$ & $\begin{array}{l}-1.458158 \\
(-6.90178) \\
{[0.31891]} \\
\end{array}$ \\
\hline $\begin{array}{l}\text { Coefficient on the } \\
\text { nominal interest rate } \\
\text { (t-statistic) } \\
\text { [standard error] }\end{array}$ & $\begin{array}{l}111.2116 \\
(5.33479) \\
{[20.8465]}\end{array}$ & $\begin{array}{l}112.7742 \\
(5.31116) \\
{[21.2334]}\end{array}$ & $\begin{array}{l}0.683780 \\
(5.71150) \\
{[0.11972]} \\
\end{array}$ & $\begin{array}{l}0.693806 \\
(5.67022) \\
{[0.12236]}\end{array}$ \\
\hline $\begin{array}{l}\text { Coefficient on the real } \\
\text { interest rate } \\
\text { (t-statistic) } \\
\text { [standard error] }\end{array}$ & $\begin{array}{l}-136.7328 \\
(-10.2753) \\
{[13.3070]}\end{array}$ & $\begin{array}{l}-140.0479 \\
(-10.3933) \\
{[13.4748]}\end{array}$ & $\begin{array}{l}-125.9374 \\
(-10.4394) \\
{[12.0637]}\end{array}$ & $\begin{array}{l}-128.7815 \\
(-10.5038) \\
{[12.2604]}\end{array}$ \\
\hline $\begin{array}{l}\text { LR test: } 1^{\text {st }} \text { slope }=+1 \\
\text { Actual } \chi^{2}(1) \\
\text { P-value }\end{array}$ & $\begin{array}{l}1.374844 \\
0.240981 \\
\end{array}$ & $\begin{array}{l}1.180209 \\
0.277314 \\
\end{array}$ & $\begin{array}{l}0.376228 \\
0.539629 \\
\end{array}$ & $\begin{array}{l}0.292296 \\
0.588753\end{array}$ \\
\hline $\begin{array}{l}\text { LR test: } 2^{\text {nd }} \text { slope }=-1 \\
\text { Actual } \chi^{2}(1) \\
\text { P-value }\end{array}$ & $\begin{array}{l}0.001547 \\
0.968625\end{array}$ & $\begin{array}{l}0.025756 \\
0.872498 \\
\end{array}$ & $\begin{array}{l}1.322256 \\
0.250187\end{array}$ & $\begin{array}{l}1.521075 \\
0.217457\end{array}$ \\
\hline $\begin{array}{l}\text { LR test: joint test on the } \\
\text { above two slopes } \\
\text { Actual } \chi^{2}(2) \\
\text { P-value }\end{array}$ & $\begin{array}{l}3.195833 \\
0.202318 \\
\end{array}$ & $\begin{array}{l}3.195214 \\
0.202380 \\
\end{array}$ & $\begin{array}{l}7.659972 \\
0.021710 \\
\end{array}$ & $\begin{array}{l}7.715088 \\
0.021120 \\
\end{array}$ \\
\hline
\end{tabular}

Three coefficient hypothesis restrictions are tested by likelihood ratio tests that are $\chi^{2}$ distributed under the null. The first hypothesis is that the slope coefficient on the money stock is +1 . In all four regressions this hypothesis fails to be rejected at marginal significance levels much higher than $10 \%$. This implies money neutrality. Money neutrality means that the specification of the model is appropriate, because such neutrality is a basic requirement in many theoretical models. The second hypothesis is that the slope on the scale variable is -1 . In all four regressions this hypothesis fails to be rejected at marginal significance levels much higher than $10 \%$. This implies the absence of economies and diseconomies of scale. The third hypothesis is whether the two slope coefficients are jointly +1 and -1 . For the two estimates of equation (9) this joint hypothesis fails to be rejected at 
marginal significance levels much higher than $10 \%$. However for the two estimates of equation (12) the actual marginal significance levels of the joint hypothesis are $2.171 \%$ and $2.112 \%$, less than a $5 \%$ marginal significance level, but higher than a $2 \%$ marginal significance level. This differential result in significance may be due to the fact that the specification of equation (9) is better than that of equation (12) or else that the industrial production index is a bad proxy for the scale variable.

The semi-elasticity of money demand of the nominal interest rate is -111.2116 and -112.7742 (Table 3 ). These estimates are monthly because the interest rate variable is divided by 1200 in the estimation procedure. For comparability purposes the semi-elasticity must be divided by 1200 and is measured as -0.09268 and -0.09398 . These two estimates are close to -0.10 , which is the value suggested by Stock and Watson (1993) for the $20^{\text {th }}$ century, and close to the estimates in Ball (2001), but higher, in absolute values, than the estimates in Friedman and Schwartz (1982). The average of the 10-year Treasury rate over the sample period is $7.062 \%$, implying two estimates of the interest rate elasticity of money demand: -0.6545 , and -0.6637 . These estimates are close to the estimates of equation (12), and which are -0.6838 and -0.6938 (Table 3), and close to the estimates for the United Kingdom which range between -0.499 and -0.905 (Matthews et al., 2004).

The semi-elasticity of the real interest rate in the foreign exchange rate cointegration regression has four estimates (Table 3). The coefficient values in Table 3 must also be divided by 1200 for comparability purposes, and doing so, the semi-elasticities become respectively for the four cointegration regressions in Table 3: -0.1139, $-0.1167,-0.1049$, and -0.1073 . These estimates are so close to each other that it is difficult to favor one specification over another. The average real rate is $3.8918 \%$ per annum, implying four real rate elasticities, which are also close to each other: $-0.4433,-0.4542,-0.4083$, and -0.4176 .

Table 4. Coefficients on the error-correction lagged residuals

Error-correction model of each of the following cointegration regression

\begin{tabular}{|c|c|c|c|c|}
\hline $\begin{array}{l}\text { Dependent variable: } \\
\text { First-difference of the log of each of the } \\
\text { below variable with exceptions (see the } \\
\text { table Notes). }\end{array}$ & $\begin{array}{l}\text { Equation (9) } \\
\text { with the seasonally } \\
\text { adjusted money } \\
\text { stock }\end{array}$ & $\begin{array}{l}\text { Equation (9) } \\
\text { with the not } \\
\text { seasonally adjusted } \\
\text { money stock }\end{array}$ & $\begin{array}{l}\text { Equation (12) } \\
\text { with the seasonally } \\
\text { adjusted money } \\
\text { stock }\end{array}$ & $\begin{array}{c}\text { Equation (12) } \\
\text { with the not } \\
\text { seasonally adjusted } \\
\text { money stock }\end{array}$ \\
\hline The foreign exchange rate & -0.005707 & -0.005449 & -0.007609 & -0.007281 \\
\hline (t-statistic) & $(-1.72893)$ & $(-1.69688)$ & $(-1.99912)$ & $(-1.96452)$ \\
\hline [standard error] & {$[0.00330]$} & {$[0.00321]$} & {$[0.00381]$} & {$[0.00371]$} \\
\hline The money supply & 0.000566 & 0.002895 & 0.001633 & 0.004383 \\
\hline (t-statistic) & $(0.54306)$ & $(1.76375)$ & $(1.30786)$ & $(2.28058)$ \\
\hline [standard error] & {$[0.00104]$} & {$[0.00164]$} & {$[0.00125]$} & {$[0.00192]$} \\
\hline The industrial production index & 0.003770 & 0.003650 & 0.003906 & 0.003840 \\
\hline (t-statistic) & $(2.83129)$ & $(2.80684)$ & $(2.52291)$ & $(2.54028)$ \\
\hline [standard error] & {$[0.00133]$} & {$[0.00130]$} & {$[0.00155]$} & {$[0.00151]$} \\
\hline The nominal interest rate & $-9.13 \mathrm{E}-05$ & $-9.14 \mathrm{E}-05$ & -0.014051 & -0.014711 \\
\hline (t-statistic) & $(-1.83906)$ & $(-1.90164)$ & $(-1.30151)$ & $(-1.40573)$ \\
\hline [standard error] & {$[5.0 \mathrm{E}-05]$} & {$[4.8 \mathrm{E}-05]$} & {$[0.01080]$} & {$[0.01046]$} \\
\hline The real interest rate & -0.004013 & -0.003893 & -0.004670 & -0.004506 \\
\hline (t-statistic) & $(-8.02174)$ & $(-7.96329)$ & $(-8.11342)$ & $(-8.00325)$ \\
\hline [standard error] & {$[0.00050]$} & {$[0.00049]$} & {$[0.00058]$} & {$[0.00056]$} \\
\hline
\end{tabular}

Notes: For the nominal interest rate error-correction model, the dependent variable is the first-difference of the rate for the two specifications of equation (9), and is the first-difference of the logs of the rate for the two specifications of equation (12). The first-difference of the real interest rate is the dependent variable in the error-correction model of the real interest rate.

Weak exogeneity is now tested following Engle et al. (1983) and Rapach and Wohar (2002). A variable is weakly exogenous if the coefficient on the lagged error-correction residual in the Vector Error-Correction Model (VECM) is statistically insignificant (Table 4). The foreign exchange rate is weakly exogenous only in the first specification of the model, i.e. equation (9), in which the nominal interest rate enters linearly and is not logged. The money supply is weakly exogenous in 3 out of 4 cases. The scale variable, the industrial production index, is not weakly exogenous, although the error-correction coefficient has the wrong sign. The nominal interest rate is 
weakly exogenous in all 4 cases. The real interest rate is not weakly exogenous, and the error-correction coefficient has the correct sign and is highly significant statistically. It seems that the real interest rate and probably the scale variable bear the brunt of the adjustment to the long run, i.e. their adjustment restores long run equilibrium. These results are in sharp contrast to Rapach and Wohar (2002) who find that the scale variable is weakly exogenous and that the money stock is the variable that achieves the adjustment towards the long run.

In order to represent the dynamic impact of a shock in the log of the money stock on the log of the trade-weighted exchange rate of the US dollar a Vector Autoregressive Model (VAR) comprising all the above 5 variables is estimated. The number of lags is four, selected according to the Akaike Information Criterion. The response of the $\log$ of the US dollar to the shock in the log of the seasonally adjusted US money stock is portrayed in Figure 1. This figure shows that initially the response of the US dollar is negative, i.e. the US dollar appreciates for about 6 months, after which it begins depreciating gradually until the final effect is almost constant and positive, significantly above the zero line. This long run impact reflects the neutrality of the money stock. The short run overshooting, or appreciation of the US dollar, the gradual depreciation, and the long run return to equilibrium, are consistent with the Dornbusch overshooting hypothesis (Dornbusch, 1976). This has received empirical support lately, as shown by the evidence in Bjørnland (2009), where overshooting occurs within 1-2 quarters, a period which is consistent with the finding of a 6-month overshooting in this paper.

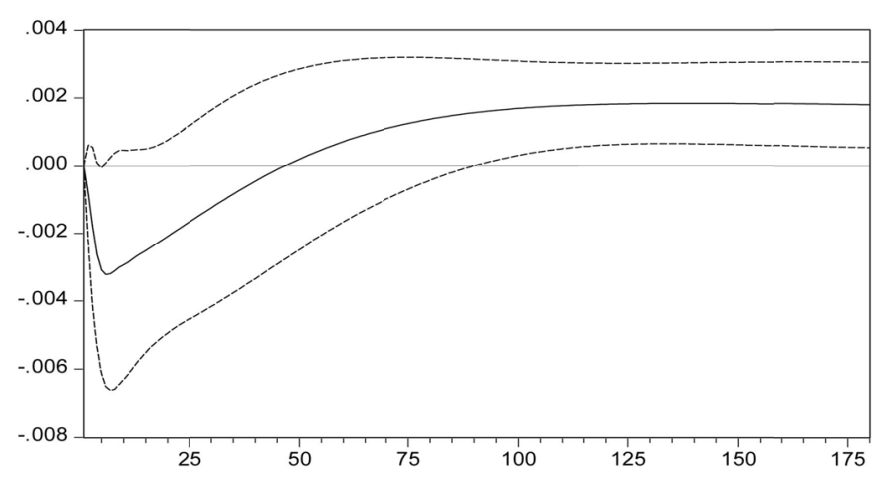

Figure 1. Response of the log of the US dollar to a one standard deviation Cholesky innovation in the log of the US money stock

Figure 2 portrays the dynamic impact of an innovation in the US money stock on the nominal interest rate. Again overshooting is the main characteristic in this figure. The nominal rate shoots up initially for about 5 months. Then it gradually falls, reaching a new long run equilibrium which is significantly below the zero line. The nominal rate is permanently lower than at the start. The behavior of the nominal rate in Figure 2 is consistent with the behavior of the foreign exchange rate in Figure 1 and the two follow from the same theoretical principle.

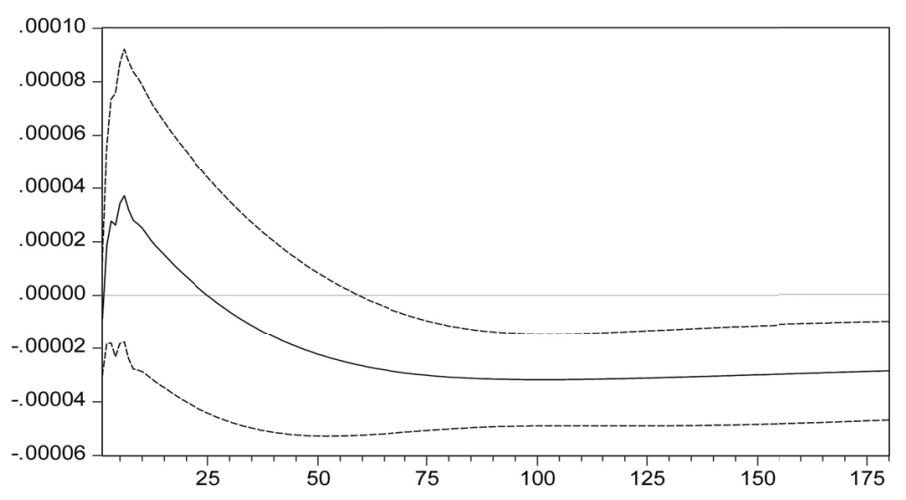

Figure 2. Response of the US 10-year Treasury rate to a one standard deviation Cholesky innovation in the log of the US money stock 


\section{Conclusion}

This paper has estimated successfully a version of the monetary approach to foreign exchange rates applied to the US dollar for the post-1973 floating exchange rate period. The variables that explain the loss in the international purchasing power of the US dollar are: the US money stock, a US scale variable, a US nominal interest rate and a US real yield. Since all variables are integrated of order 1, the econometric procedure adopted is cointegration, which enables carrying out tests for a long run relation.

There is strong support for only one cointegration equation in all four estimated regressions. All coefficients have the correct sign and are highly significant statistically. The null hypothesis that the coefficient on the money stock variable is equal to +1 fails to be rejected in all four regressions. This supports money neutrality, which is a crucial constituent of many macro models. The null hypothesis that the coefficient on the scale variable is equal to -1 fails to be rejected in all four regressions. This excludes economies and diseconomies of scale. The joint null hypothesis that both of the above two constraints hold fails to be rejected at marginal significance levels much higher than $10 \%$ for the two regressions based on equation (9). However, for the two regressions based on equation (12) this joint null hypothesis fails to be rejected at a marginal significance level higher than $2 \%$. It seems that a linear specification of the nominal interest rate variable as in equation (9) is better supported than a log specification as in equation (12), or else that the proxy for the scale variable is a bad proxy. Finally, the adjustment to the long run falls upon the real interest rate and probably also upon the scale variable. There is evidence that the foreign exchange rate, the money supply, and the nominal interest rate are all weakly exogenous.

The evidence on the estimated model, on money neutrality, and on the absence of economies and diseconomies to scale should urge economists to regain confidence in this monetary model, and should assure them that foreign exchange rate fluctuations may be justified by the fundamentals included in that model. At the very least, long run volatility of foreign exchange rates may fail to be regarded as excessive. And a more benign look upon these long run fluctuations in foreign exchange rates is warranted, especially by policy makers. If, in the long run, the level and volatility of foreign exchange rates are predictable individual investors should be more tranquil about their returns on foreign investments and these returns should turn out to be better in line with their expectations.

\section{References}

Akaike, H. (1974). A new look at the statistical model identification. IEEE Transactions on Automatic Control, AC-19, 716-723. http://dx.doi.org/10.1109/TAC.1974.1100705

Azar, S. (2012a). Oil prices, US inflation, US money supply, and the US dollar. Working paper, Beirut: Haigazian University.

Azar, S. (2012b). Commodity price indexes and the US money supply in the long run: further tests. Journal of Financial Markets Research, 4, 35-43.

Azar, S. (2012c). Commodity prices and the US money supply in the long run. International Journal of Trade and Global Markets, 5(3/4), 316-335. http://dx.doi.org/10.1504/IJTGM.2012.049983

Azar, S. (2012d). Commodity futures and the US money supply. The Empirical Economics Letters, 11(10), 1039-1046.

Ball, L. (2001). Another look at long-run money demand. Journal of Monetary Economics, 47, 31-44. http://dx.doi.org/10.1016/S0304-3932(00)00043-X

Bilson, J. F. O. (1978). The monetary approach to the exchange rate: Some empirical evidence. IMF Staff Papers, 25, 48-75. http://dx.doi.org/10.2307/3866655

Bjørnland, H. C. (2009). Monetary policy and exchange rate overshooting: Dornbusch was right after all. Journal of International Economics, 79, 64-77. http://dx.doi.org/10.1016/j.jinteco.2009.06.003

Browne, F., \& Cronin, D. (2007). Commodity prices, money and inflation. ECB working paper, Retrieved from SSRN: http://ssrn.com/abstract $=970626$.

Browne, F., \& Cronin, D. (2010). Commodity prices, money and inflation. Journal of Economics and Business, 62, 331-345. http://dx.doi.org/10.1016/j.jeconbus.2010.02.003

Diebold, F. X., \& Nerlove, M. (1990). Unit roots in economic time series: a selective survey. In Rhodes, G. F., \& Fomby, T. B. (Eds.), Advances in econometrics (pp. 3-69). J Greenwich: JAI Press. 
Dornbusch, R. (1976). Expectations and exchange rate dynamics. Journal of Political Economy, 84, 1161-1176. http://dx.doi.org/10.1086/260506

Dornbusch, R. (1980). Exchange rate economics: Where do we stand? Brookings Papers on Economic Activity, 1, 145-185.

Elliott, G., Rothenberg, T. J., \& Stock, J. H. (1996). Efficient tests for an autoregressive unit root. Econometrica, 64, 813-836. http://dx.doi.org/10.2307/2171846

Engle, R. F., \& Granger, C. W. J. (1987). Cointegration and error-correction: Representation, estimation an testing. Econometrica, 55, 251-276. http://dx.doi.org/10.2307/1913236

Engle, R. F., Hendry, D., \& Richard, J. F. (1983). Exogeneity. Econometrica, 51, 277-304. http://dx.doi.org/10.2307/1911990

Fama, E. (1981). Stock returns, real activity, inflation, and money. American Economic Review, 71, 545-565.

Fisher, I. (1930). The theory of interest. New York: McMillan, New York.

Fleming, J, M. (1962). Domestic financial policies under fixed and under floating exchange rates. IMF Staff Papers, 9, 369-379. http://dx.doi.org/10.2307/3866091

Friedman, M., \& Schwartz, A. J. (1982). Monetary trends in the United States and the United Kingdom. Chicago: Chicago University Press.

Groen, J. J. J. (2000). The monetary exchange rate model as a long-run phenomenon. Journal of International Economics, 52, 299-319. http://dx.doi.org/10.1016/S0022-1996(00)00061-1

Hodrick, R. J. (1978). An empirical analysis of the monetary approach to the determination of the exchange rate. In Frenkel, J. A., \& Johnson, H. G. (Eds.), The economics of exchange rates (pp. 97-128). Reading, MA: Addison-Wesley.

Johansen, S. (1991). Estimation and hypothesis testing of cointegration vectors in Gaussian vector autoregressive models. Econometrica, 59, 1551-1580. http://dx.doi.org/10.2307/2938278

Johansen, S. (1995). Likelihood-based inference in cointegrated vector autoregressive models. Oxford: Oxford University Press. http://dx.doi.org/10.1093/0198774508.001.0001

Kwiatkowski, D., Phillips, P. C. B., Schmidt, P., \& Shin, Y. (1992). Testing the null hypothesis of stationarity against the alternative of a unit root. Journal of Econometrics, 54, 159-178. http://dx.doi.org/10.1016/0304-4076(92)90104-Y

Lizardo, R. A., Mollick, A. V. (2010). Oil price fluctuations and U.S. dollar exchange rates. Energy Economics, 32, 399-408. http://dx.doi.org/10.1016/j.eneco.2009.10.005

MacDonald, R. (1988). Floating exchange rates, theories and evidence. Hyman, London: Unwin. http://dx.doi.org/10.4324/9780203427484

Matthews, K., Paya, I., \& Peel, D. A. (2004). Alan Walters and the demand for money: An empirical retrospective. In P. Minford (Ed.), Money Matters (pp. 148-168). Northampton, MA: Edward Elgar.

Meese, R. A., \& Rogoff, K. (1983). Empirical exchange rate models of the seventies: Do they fit out of sample? Journal of International Economics, 14, 3-24. http://dx.doi.org/10.1016/0022-1996(83)90017-X

Mills, T. C. (1999). The econometric modelling of financial time series. (2nd ed.). Cambridge, UK: Cambridge University Press. http://dx.doi.org/10.1017/CBO9780511754128

Mills, T. C., \& Markellos, R. N. (2008). The econometric modelling of financial time series (3rd ed.). Cambridge, UK: Cambridge University Press. http://dx.doi.org/10.1017/CBO9780511817380

Mundell, R. A. (1968). International economics. New York: Macmillan.

Rapach, D. E., \& Wohar, M. E. (2002). Testing the monetary model of exchange rate determination: New evidence from a century of data. Journal of International Economics, 58, 359-385. http://dx.doi.org/10.1016/S0022-1996(01)00170-2

Rey, S. (2009). L'apport du NATREX à la modélisation des taux de change d'équilibre : Théorie et application au dollar canadien. L'Actualité Économique, Revue d'Analyse Économique, 85, 131-181. http://dx.doi.org/10.7202/044252ar

Ross, S. A., Westerfield, R. W., \& Jaffe, J. F. (2010). Corporate finance. (9th ed.). Boston: McGraw-Hil. 
Schwert, G. (1987). Effects of model specification on tests for unit roots in macroeconomic data. Journal of Monetary Economics, 20, 73-105. http://dx.doi.org/10.1016/0304-3932(87)90059-6

Stein, J. L., Allen, P. R., \& Associates (Eds.). (1997). Fundamental determinants of exchange rates. Oxford: Oxford University Press.

Stock, J. H., \& Watson, M. W. (1993). A simple estimator of cointegrating vectors in higher order integrated systems. Econometrica, 61, 783-820. http://dx.doi.org/10.2307/2951763 